\title{
Tanggung Jawab Sosial Badan Usaha Milik Negara dalam Menumbuhkan Kemandirian Masyarakat di Sulawesi Selatan
}

\begin{abstract}
DATA NASKAH
Masuk: 3 September 2016 Diterima: 19 Oktober 2016

Terbit: 1 Juni 2017

KORESPONDEN PENULIS:

STMIK Dipanegara Makassar,

Jl. Perintis Kemerdekaan KM.9,

Tamalanrea Indah, Tamalanrea, Kota Makassar, Sulawesi Selatan 90245.

Email: arasjaya@yahoo.co.id
\end{abstract}

\author{
Abdul Rauf
}

\section{ABSTRACT}

State-owned enterprises (SOEs) social responsibility is important to maintain continuity of production to the goal of building the social legitimacy, even the implementation of social responsibility in SOEs has become a liability in accordance with the legislation in force. However, reality shows that the implementation of social responsibility by the state has not been able to play an optimal role in fostering self-reliance. Therefore, the issues to be discussed is how a form of implementation of social responsibility SOEs to foster self-reliance. This research was conducted by examining theories and provisions of relevant laws and connected with the application in the field. The research was conducted on a five (5) SOEs in South Sulawesi as a sample. The results showed that the implementation of social and environmental responsibility by the state is a form of concern on the part of the company on surrounding communities and the environment, which is implemented in the form of the Partnership and Community Development Program coupled with other social programs are referred to as BUMN Peduli. However, in order to foster self-reliance of society, there should be synchronization between the activities of the partnership program with environmental development program. Provide guidance to the public should also be conducted on an ongoing basis from the provision of training, provision of capital, mentoring, until the people who nurtured can be sought independently.

Key word: Corporate Social Responsibility, BUMN, PKBL

\section{ABSTRAK}

Tanggung jawab sosial BUMN penting untuk menjaga kelangsungan produksi sampai pada tujuan membangun legitimasi sosial, bahkan pelaksanaan tanggung jawab sosial pada BUMN telah menjadi suatu kewajiban menurut peraturan perundang-undangan yang berlaku. Namun, kenyataan menunjukkan bahwa pelaksanaan tanggung jawab 
sosial oleh BUMN belum mampu berperan secara optimal dalam menumbuhkan kemandirian masyarakat. Oleh karena itu, permasalahan yang akan dibahas adalah bagaimana wujud pelaksanaan tanggung jawab sosial BUMN yang dapat menumbuhkan kemandirian masyarakat. Penelitian ini dilakukan dengan mengkaji teoriteori maupun ketentuan undang-undang yang relevan dan dihubungkan dengan penerapannya secara konkrit di lapangan. Penelitian ini dilaksanakan pada 5 (lima) BUMN di Sulawesi Selatan sebagai sampel. Hasil penelitian menunjukkan bahwa pelaksanaan tanggung jawab sosial dan lingkungan oleh BUMN merupakan wujud kepedulian dari pihak perseroan terhadap masyarakat sekitar dan lingkungan, yang dilaksanakan dalam bentuk Program Kemitraan dan Bina Lingkungan (PKBL) ditambah dengan program-program sosial lain yang disebut dengan istilah BUMN Peduli. Namun demikian, untuk menumbuhkan kemandirian masyarakat, perlu ada sinkronisasi kegiatan antara program kemitraan dengan program bina lingkungan. Pembinaan kepada masyarakat juga harus dilaksanakan secara berkelanjutan mulai dari pemberian diklat, penyediaan modal, pendampingan, sampai masyarakat yang dibina dapat berusaha secara mandiri.

Kata Kunci: Tanggungjawab Sosial dan Lingkungan, BUMN, PKBL

\section{PENDAHULUAN}

Perusahaan sesungguhnya tidak hanya memiliki sisi tanggung jawab ekonomis kepada para shareholders seperti memperoleh profit dan menaikkan harga saham, atau tanggung jawab legal kepada pemerintah, seperti membayar pajak, memenuhi persyaratan analisis mengenai dampak lingkungan (Amdal) dan ketentuan lainnya (Dwi Kartini, 2009:3). Namun, jika perusahaan ingin tetap eksis dan acceptable, maka harus pula menjalankan tanggungjawabnya yang bersifat sosial (Yusuf Wibisono, 2007:13).

Pada hakikatnya konsep tanggung jawab sosial perusahaan sesuai dengan nilai-nilai yang terkandung dalam Pancasila khususnya pada Sila ke 5 yaitu "keadilan sosial bagi seluruh rakyat Indonesia". Nilai-nilai Pancasila dijabarkan lebih lanjut dalam UUD 1945. Ketentuan Pasal 33 UUD 1945, Bab XIV tentang Perekonomian Nasional dan Kesejahteraan Sosial, menjadi dasar pengaturan lebih lanjut dalam hal pengelolaan kekayaan negara dalam upaya mewujudkan kesejahteraan sosial bagi seluruh rakyat Indonesia.

Badan Usaha Milik Negara (BUMN) merupakan perpanjangan tangan pemerintah dalam mengelola potensi-potensi kekayaan negara. BUMN dituntut untuk berfungsi sebagai instrument pembangunan nasional dan kebijakan sosial (Fajar Nursahid, 2006: 6). Oleh karena itu, BUMN mempunyai peran yang sangat strategis dalam upaya mencapai tujuan pembangunan nasional yaitu mewujudkan masyarakat yang sejahtera, adil, dan makmur.

Sesuai dengan ketentuan Pasal 2 ayat (1), Undang-undang No.19 Tahun 2003 tentang Badan Usaha Milik Negara, dinyatakan bahwa salah satu maksud dan tujuan pendirian BUMN adalah turut aktif memberikan bimbingan dan bantuan kepada pengusaha golongan ekonomi lemah, koperasi, dan masyarakat. Ketentuan ini menjadi salah satu dasar sehingga BUMN memiliki tanggung jawab yang bersifat sosial terhadap masyarakat maupun tanggung jawab terhadap lingkungan. Tanggung jawab sosial BUMN juga didasarkan pada ketentuan Pasal 74 Undang-undang No. 40 Tahun 2007 tentang Perseroan Terbatas. Hal ini dipertegas dengan dikeluarkannya Surat Edaran Kementerian Negara BUMN No. SE-07/MBU/2008 tentang Pelaksanaan PKBL dan Penerapan Pasal 74 Undang-undang Perseroan Terbatas. Hal ini menunjukkan bahwa pengaturan tentang tanggung jawab sosial BUMN selain didasarkan pada Undang-undang BUMN sendiri juga didasarkan pada Undang-undang Perseroan Terbatas. Setelah diundangkan berbagai peraturan tersebut, banyak perusahaan, baik perusahaan asing maupun BUMN yang telah melaksanakan berbagai program tanggungjawab sosial perusahaan (Isnaini Muallidin dan leli Joko Suryono, 2015: 128)

Walaupun tanggung jawab sosial BUMN telah diatur dengan tegas pada berbagai ketentuan hukum yang berlaku, bahkan sudah diwajibkan sebagaimana yang diatur dalam ketentuan Pasal 2 Peraturan Menteri BUMN No. PER-09/ MBU/07/2015 tentang Program Kemitraan dan Bina Lingkungan, namun kenyataan menunjukkan bahwa pelaksanaan tanggung jawab sosial BUMN masih belum mampu mewujudkan kondisi sosial masyarakat yang tangguh dan mandiri, khususnya bagi pengusaha kecil dan masyarakat golongan ekonomi lemah. Oleh karena itu, permasalahan 


\section{MEDIA
HUKUM}

utama yang akan dibahas dalam penelitian ini adalah bagaimana wujud pelaksanaan tanggung jawab sosial BUMN yang dapat menumbuhkan kemandirian masyarakat.

\section{METODE PENELITIAN}

\section{Jenis dan Tipe Penelitian}

Penelitian ini merupakan jenis penelitian normatif dan empiris di bidang hukum perusahaan, yaitu penelitian hukum yang mengkaji baik dari segi pengaturannya maupun pada penerapannya di lapangan. Tipe penelitian hukum ini bersifat deskriptif, yaitu memaparkan secara lengkap, rinci, dan sistematis.

\section{Populasi dan Sampel}

Populasi dalam penelitian ini adalah BUMN yang berbentuk perseroan terbatas dengan jumlah keseluruhan sebanyak 26 perusahaan (BPS Sulsel: 2009). Perusahaan BUMN yang dijadikan sampel ditentukan dengan pertimbangan bahwa perusahaan tersebut memiliki aktifitas cukup menonjol dalam pelaksanaan tanggung jawab sosial dan lingkungan. Jumlah sampel yang diambil dalam penelitian ini sebanyak 5 perusahaan. Sampel ditentukan dengan cara sengaja (purposive sampling). Responden dalam penelitian ini terdiri atas pimpinan perusahaan dan karyawan pada setiap BUMN sampel, ditambah dengan 5 pengusaha kecil menengah yang diikutsertakan pada program PKBL. Pengumpulan data dilakukan dengan cara pembagian kuesioner dan wawancara. Kuesioner diberikan kepada setiap responden di masing-masing BUMN.

\section{Lokasi Penelitian}

Penelitian ini dilakukan pada beberapa perusahaan BUMN di Provinsi Sulawesi Selatan. Penentuan lokasi penelitian didasarkan pada pertimbangan bahwa masyarakat Sulawesi Selatan pada umumnya masih sangat membutuhkan berbagai bentuk program bantuan sosial, termasuk dari perusahaan BUMN. Selain itu, peraturan yang menjadi dasar pelaksanaan tanggung jawab sosial dan lingkungan pada BUMN berlaku secara nasional, sehingga setiap BUMN memiliki pedoman yang sama tanpa melihat lokasi atau wilayah operasional BUMN yang bersangkutan.

\section{HASIL PENELITIAN DAN ANALISIS}

\section{Hakikat Tanggung Jawab Sosial dan}

\section{Lingkungan}

Tanggung jawab sosial dan lingkungan pada dasarnya tumbuh dan berakar dari kesadaran perusahaan secara internal untuk berperilaku baik dan etis, serta memperhatikan kepentingan semua pihak yang terkait dengan aktivitas perusahaan (Ismail Solihin, 2008:12). Namun demikian, nuansa moral dan etis yang tampak dalam pelaksanaan tanggung jawab sosial perusahaan bukanlah kenyataan yang sesungguhnya. Tanggung sosial perusahaan dilaksanakan bukan semata-mata karena ingin berbuat baik atau berderma secara ikhlas tanpa pamrih, melainkan karena adanya tuntutan hukum atau tuntutan kepentingan dari pihak-pihak yang terkait. Perusahan pada prinsipnya dituntut agar aktivitas yang dilakukannya tidak menimbulkan dampak yang dapat merugikan kepentingan masyarakat dan lingkungan (Priyanto Susiloadi, 2008: 123-140).

Tuntutan-tuntutan seperti itulah yang memaksa perusahaan, termasuk Badan Usaha Milik Negara (BUMN) untuk melaksanakan tanggung jawab sosialnya. Oleh karena itu, praktik tanggung jawab sosial dan lingkungan yang dijalankan oleh perusahaan khususnya BUMN tidak bersifat sukarela. Tanggung jawab sosial perusahaan pada hakikatnya merupakan sesuatu yang harus dijalankan, agar perusahaan dapat berjalan dengan baik dan berkelanjutan (sustainable).

Berdasarkan ketentuan Pasal 33 ayat (3) UUD 1945, pengelolaan perekonomian nasional bertujuan untuk mewujudkan sebesar-besar kemakmuran bagi seluruh rakyat Indonesia. Hal ini mendasari lahirnya perusahaan-perusahaan milik negara yang disebut dengan istilah Badan Usaha Milik Negara (BUMN). Badan usaha ini merupakan bentuk perpanjangan tangan pemerintah dalam melaksanakan kegiatan pengelolaan terhadap potensi-potensi kekayaan alam nasional maupun cabang-cabang produksi yang dianggap penting oleh negara.

Sesuai dengan ketentuan Pasal 2 huruf e Undang-undang No.19 Tahun 2003 tentang BUMN maksud dan tujuan pendirian BUMN adalah turut aktif memberikan bimbingan dan bantuan kepada pengusaha golongan ekonomi lemah, koperasi, dan masyarakat. Lebih lanjut, dalam ketentuan 
Pasal 88 ayat (1) Undang-undang BUMN diatur pula bahwa, BUMN dapat menyisihkan sebagian laba bersihnya untuk keperluan pembinaan usaha kecil dan koperasi serta pembinaan masyarakat. Ketentuan-ketentuan tersebut di atas menunjukkan bahwa pelaksanaan tanggung jawab sosial dan lingkungan pada BUMN merupakan tugas konstitusional yang harus dilaksanakan dalam rangka mewujudkan kesejahteraan bagi seluruh rakyat Indonesia. Oleh karena itu, sasaran pelaksanaan tanggung jawab sosial dan lingkungan pada BUMN bukan hanya ditujukan kepada pihak-pihak yang terkait dengan aktivitas perseroan, akan tetapi bagi seluruh rakyat Indonesia. Hal ini tentu agak berbeda dengan konsep tanggung jawab sosial pada perusahaan swasta, yang lebih menitik beratkan pada upaya pemenuhan kepentingan stakeholder yaitu pihak-pihak yang berpengaruh atau terpengaruh oleh aktivitas perusahaan.

\section{Pentingnya Tanggung Jawab Sosial dan}

\section{Lingkungan (TJSL) diatur Berdasarkan}

\section{Hukum}

Teori keadilan menurut John Rawls dengan prinsip ketidaksamaannya (the principle of difference) menekankan bahwa, ketidaksamaan yang ada diantara manusia dalam bidang ekonomi dan sosial harus diatur sedemikian rupa, sehingga ketidaksamaan tersebut dapat menguntungkan setiap orang, terutama bagi orang-orang yang secara kodrati kurang beruntung (Uzair Fauzan dan Heru Prasetyo, 2006:314). Hal ini menunjukkan bahwa perlu ada peran pemerintah dalam mengatur bidang ekonomi maupun sosial. Terlebih lagi teori negara kesejahteraan, yang pada dasarnya memberikan peran besar kepada negara atau pemerintah untuk menjamin kesejahteraan warganya (Ridwan HR, 2007:8). Begitu pula dengan Wealth Maximization Theory of Justice yang sudah dari awal menggunakan pendekatan hukum dalam menganalisis masalah-masalah ekonomi dan menekankan bahwa hukum seharusnya mempromosikan efisiensi (Richard A.Posner, 1981:7).

Uraian tersebut di atas menunjukkan bahwa dari sudut pandang teoritis pendistribusian sumber daya atau potensipotensi ekonomi nasional penting diatur berdasarkan hukum. Demikian pula halnya dengan tanggung jawab sosial perusahaan terutama pada BUMN juga harus diatur dalam suatu aturan hukum yang mengikat, sehingga tanggung jawab sosial perusahaan yang awalnya dipahami sebagai tanggung jawab moral dan bersifat sukarela, kemudian bergeser menjadi tanggung jawab hukum yang bersifat mandatory.

Perbandingan tentang tanggung jawab sosial perusahaan sebagai tangung jawab moral dan sebagai tanggung jawab hukum digambarkan dalam bentuk bagan 1 .

Pentingnya tanggung jawab sosial perusahaan diatur berdasarkan hukum juga dapat dilihat dari sudut pandang empiris. Aktivitas yang dilakukan oleh perusahaan dapat menimbulkan dampak yang merugikan, baik terhadap masyarakat sekitar maupun terhadap lingkungan. Merugikan pihak lain atau menimbulkan pencemaran lingkungan merupakan bentuk perbuatan melanggar hukum. Oleh karena itu, perusahaan seharusnya dapat dituntut berdasarkan hukum, sehingga wajib memberikan kompensasi atau melakukan upaya perbaikan lingkungan, baik terhadap lingkungan sosial maupun lingkungan hidup termasuk upaya-upaya peningkatan taraf hidup masyarakat sehingga menjadi lebih mandiri.

Pemahaman yang menganggap bahwa tanggung jawab sosial perusahaan merupakan wujud kedermawanan sosial dengan sifatnya yang sukarela tidak selaras dengan akibat yang ditimbulkannya, karena dasar pelaksanaannya hanya merupakan tanggung jawab moral, sementara akibatnya adalah akibat hukum. Hal ini akan menimbulkan kesulitan jika hendak menerapkan sanksi hukum, karena sanksi yang mungkin diterapkan dalam konteks tersebut adalah sanksi moral. Oleh karena itu, tanggung jawab sosial perusahaan seharusnya diartikan sebagai tanggung jawab hukum yang sifatnya wajib. Prinsip pertanggungjawaban hukum dalam hal ini merupakan implementasi paradigma interactive justice (Edmon Makarim,2010:14), dimana dasar keberadaan tanggung jawab adalah untuk menegakkan kewajiban yang seharusnya diemban oleh setiap orang dalam melakukan interaksi dengan orang lain.

Berdasarkan uraian di atas, dapat dipahami bahwa terdapat dua alasan utama yang dapat dijadikan dasar, sehingga tanggung jawab sosial perusahaan perlu diwajibkan, yaitu: 


\section{MEDIA
HUKUM}

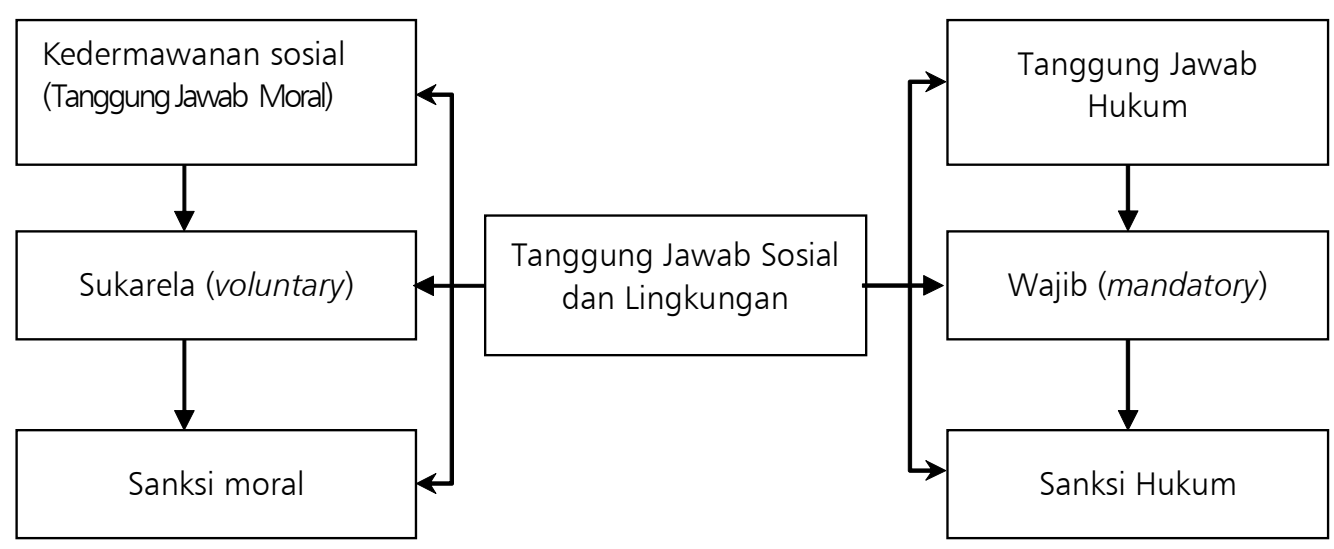

Bagan 1

Perbandingan Tanggung Jawab Sosial Perusahaan Sebagai Tangung Jawab Moral dan Sebagai Tanggung Jawab Hukum

1) Dilihat dari sudut pandang akibat yang ditimbulkannya. Pandangan bahwa tanggung jawab sosial dan lingkungan adalah bentuk kedermawanan sosial yang sifatnya sukarela, tidak sejalan dengan akibat yang ditimbulkannya.

2) Dilihat dari sudut pandang keadilan, bahwa membiarkan pihak lain menderita kerugian tanpa dasar yang cukup untuk dapat melakukan tuntutan hukum merupakan suatu bentuk ketidakadilan. Oleh karena itu, tanggung jawab sosial dan lingkungan perlu diwajibkan.

Menetapkan tanggung jawab sosial perusahaan sebagai tanggung jawab hukum akan memberikan posisi yang sederajat bagi semua pihak. Selain itu, akan memberikan dasar bagi pihak-pihak yang dirugikan untuk melakukan tuntutan secara hukum. Jika tanggung jawab sosial perusahaan hanya dipahami sebagai bentuk kedermawanan sosial, maka posisi dari para pihak yang terkait menjadi tidak sederajat. Pihak yang memberi atau melakukan derma akan memiliki posisi yang lebih tinggi dibanding dengan pihak penerima dan jika ada kerugian sulit untuk melakukan tuntutan karena dasarnya sukarela. Namun, jika tanggung jawab sosial perusahaan dipahami sebagai tanggung jawab hukum, maka hubungan yang timbul diantara para pihak adalah hubungan hukum yang akan menimbulkan hak dan kewajiban. Perusahaan melaksanakan tanggung jawab sosialnya bukan karena sedang berderma namun menjalankan kewajibannya. Ruang lingkup pertanggungjawaban hukum dalam hal ini meliputi upaya pencegahan terjadinya resiko (preventif) sampai pada upaya penanggulangan resiko (represif).

\section{Tanggung Jawab Sosial BUMN dalam}

Mewujudkan Kemandirian Masyarakat

Tanggung jawab sosial dan lingkungan pada BUMN adalah amanah undang-undang yang sifatnya wajib sebagai wujud implementasi dari fungsi sosial atau kemanfaatan umum yang diemban oleh BUMN. Pelaksanaan tanggung jawab sosial dan lingkungan pada BUMN diwujudkan dalam bentuk Program Kemitraan dan Program Bina Lingkungan (PKBL) ditambah dengan program-program sosial lain yang disebut dengan istilah BUMN Peduli. PKBL dan programprogram sosial lain yang dijalankan oleh BUMN dimaksudkan untuk meningkatkan kualitas kehidupan sosial dan lingkungan yang bermanfaat, baik bagi perseroan sendiri, komunitas setempat, maupun bagi masyarakat secara menyeluruh. Pelaksanaan tanggung jawab sosial oleh BUMN diharapkan dapat memberi manfaat yang sebesar-besarnya bagi kemakmuran rakyat.

PKBL terbagi atas dua macam jenis program yaitu program kemitraan dan program bina lingkungan. Program kemitraan adalah program yang dimaksudkan untuk meningkatkan kemampuan ekonomi masyarakat agar menjadi tangguh dan mandiri, sedangkan program bina lingkungan adalah program pemberdayaan kondisi sosial 
masyarakat oleh BUMN. Program kemitraan diwujudkan dalam bentuk pemberian pinjaman lunak kepada pengusaha kecil dan koperasi. Berdasarkan praktik yang dijalankan oleh BUMN, pengembalian pinjaman dapat dilakukan setiap bulan atau setiap tiga bulan sekali, tergantung kebijakan BUMN pembina. Hal ini menunjukkan bahwa sesungguhnya penyaluran bantuan dana kemitraan oleh BUMN bukanlah merupakan bentuk pemberian cuma-cuma, melainkan suatu bentuk pinjaman yang harus dikembalikan walaupun bunganya tergolong cukup rendah.

Bantuan bina lingkungan diberikan dalam bentuk hibah. Pelaksanaan program bina lingkungan umumnya bersifat insidentil dan didasarkan pada proposal atau permohonan yang diajukan oleh masyarakat kepada pihak BUMN. Berdasarkan ketentuan Pasal 9 ayat (3) Peraturan Menteri BUMN Nomor: Per-09/MBU/07/2015, ditetapkan bahwa ruang lingkup program bina lingkungan meliputi bantuan korban bencana alam, bantuan pendidikan dan/atau pelatihan, bantuan peningkatan kesehatan, bantuan pengembangan prasarana dan/atau sarana umum, bantuan sarana ibadah, bantuan pelestarian alam, bantuan sosial kemasyarakatan dalam rangka pengentasan kemiskinan, serta bantuan pendidikan, pelatihan, pemagangan, pemasaran, promosi, dan bentuk bantuan lain yang terkait dengan upaya peningkatan kapasitas mitra binaan. Sedangkan jenis program sosial lain yang juga dijalankan oleh BUMN adalah program BUMN Peduli. Ruang lingkup bantuan BUMN Peduli ditetapkan oleh menteri.

Program-program sosial yang dijalankan oleh BUMN diharapkan mampu mendorong peningkatan kekuatan ekonomi masyarakat sehingga dapat terbentuk masyarakat yang lebih sejahtera dan mandiri. Namun program PKBL dan program BUMN Peduli yang dijalankan oleh BUMN masih mengandung beberapa kelemahan, khususnya jika dihubungkan dengan tujuan yang hendak dicapai yaitu mewujudkan kemandirian masyarakat. Kelemahan tersebut antara lain pada program kemitraan yang hanya ditujukan kepada golongan pengusaha kecil menengah dan koperasi. Belum ada program khusus untuk memberikan modal usaha bagi golongan masyarakat yang tidak punya pekerjaan tetap atau pengangguran. Sedangkan pada program bina lingkungan umumnya hanya berupa sumbangan-sumbangan yang bersifat insidentil dan tidak berkelanjutan. Pembinaan yang diberikan melalui program bina lingkungan dalam bentuk pendidikan dan pelatihan, tidak dilanjutkan dalam bentuk pemberian modal berupa pinjaman lunak melalui program kemitraan.

Oleh karena itu, dalam upaya mewujudkan masyarakat yang tangguh dan mandiri, maka program-program sosial yang dijalankan oleh BUMN harus memenuhi kriteria sebagai berikut:

1. Jenis kegiatan yang dilaksanakan dalam program PKBL BUMN harus berkelanjutan (sustainable), dalam arti bukan hanya sekedar rutin dilaksanakan setiap tahun, akan tetapi jenis kegiatannya juga harus berkelanjutan mulai dari pemberian pendidikan dan pelatihan, penyediaan modal dan kesempatan kerja, sampai pada upaya pendampingan sehingga masyarakat yang dibina dapat berusaha secara mandiri.

2. Pihak BUMN harus menetapkan wilayah-wilayah tertentu sebagai wilayah binaan. Dalam wilayah binaan ini ditetapkan kelompok masyarakat tertentu yang hendak dibina dengan memperhatikan kesiapan dan kesanggupan dari kelompok masyarakat yang bersangkutan. Pentingnya penetapan wilayah binaan dimaksudkan agar tidak terjadi tumpang tindih penyaluran dana bantuan sosial oleh BUMN.

3. Pihak Perseroan dapat menunjuk suatu organisasi atau lembaga tertentu yang independen untuk bertindak sebagai pelaksana teknis. Hal ini dimaksudkan untuk memudahkan semua pihak, khususnya masyarakat untuk memonitor dan mengevaluasi pelaksanaan program yang telah direncanakan.

4. Sasaran pelaksanaan program kemitraan BUMN tidak hanya ditujukan pada pengusaha kecil menengah, namun juga harus ditujukan kepada golongan masyarakat yang tidak punya pekerjaan tetap atau pengangguran. Mereka dapat dididik dan dilatih terlebih dahulu melalui program bina lingkungan, kemudian diberikan bantuan modal awal melalui program kemitraan sehingga mereka dapat berusaha secara mandiri.

Upaya pembinaan oleh BUMN kepada mitra binaannya harus dilakukan secara berkelanjutan, mulai dari tahap pendidikan dan pelatihan, pemberian modal untuk berusaha 


\section{MEDIA
HUKUM}

sampai pada pendampingannya. Masyarakat binaan akan dilepas kemudian oleh BUMN Pembina setelah mereka dapat hidup dan berusaha secara mandiri. Model kegiatan berkelanjutan dalam pelaksanaan tanggung jawab sosial BUMN untuk mewujudkan kemandirian masyarakat ditunjukkan dalam bentuk bagan 2 .

Model kegiatan berkelanjutan dalam pelaksanaan tanggung jawab sosial BUMN sebagaimana yang ditunjukkan pada bagan di atas menggambarkan bahwa kelompok masyarakat yang sudah terbentuk dan menjadi mitrabinaan BUMN, terlebih dahulu diberi bekal keterampilan melalui kegiatan pendidikan dan pelatihan. Kegiatan pendidikan dan pelatihan ini sesungguhnya merupakan salah satu jenis kegiatan dalam program bina lingkungan. Oleh karena itu, perlu ada sinkronisasi kegiatan antara program kemitraan dan program bina lingkungan. Setelah memperoleh bekal keterampilan, anggota mitrabinaan BUMN diberi peluang untuk mengajukan permohonan bantuan modal usaha melalui program kemitraan. Namun demikian, dapat pula memilih bekerja pada pihak lain sebagai karyawan, akan tetapi yang bersangkutan akan dianggap mandiri dan lepas dari binaan BUMN.

Permohonan bantuan modal usaha dapat diajukan oleh mereka yang belum punya usaha tetap maupun bagi mitra binaan yang sudah punya usaha namun bermaksud untuk lebih meningkatkan kegiatan usahanya. Upaya pendampingan akan dilakukan oleh BUMN Pembina mulai dari pemberian modal sampai pada kondisi usaha mitrabinaan dapat berjalan baik dan bankable, dalam arti bahwa usaha mitrabinaan yang bersangkutan sudah memenuhi syarat dan dapat diterima oleh pihak bank bilamana bermaksud mengajukan permohonan kredit. Mitra binaan yang sudah sampai pada tahap ini akan dianggap mandiri dan lepas dari binaan BUMN Pembina. Tanggung jawab sosial BUMN dapat dilaksanakan secara langsung oleh BUMN yang bersangkutan, namun dapat pula bermitra dengan pihak lain sebagai pelaksana teknis. Pemetaan wilayah binaan BUMN harus dilaksanakan bersama dengan pemerintah dan BUMN lain dalam suatu kawasan tertentu. Hal ini dimaksudkan agar tidak terjadi tumpang tindih dalam penyaluran program bantuan sosial. Tumpang tindih tersebut dapat terjadi antara satu BUMN dengan BUMN lain, maupun dengan pihak pemerintah yang juga menyalurkan dana-dana bantuan sosial untuk kegiatan pemberdayaan masyarakat. Pemetaan terhadap wilayah binaan BUMN juga dimaksudkan agar danadana sosial untuk kepentingan pemberdayaan masyarakat dapat tersalur secara adil dan merata.

Sasaran pelaksanaan tanggung jawab sosial BUMN tidak dapat dibatasi hanya untuk masyarakat sekitar wilayah operasional perusahaan, karena potensi-potensi kekayaan alam negara yang dikelola oleh BUMN pada hakikatnya dimaksudkan untuk mewujudkan sebesar-besar kemakmuran rakyat. Oleh karena itu, pelaksanaan tanggung jawab sosial dan lingkungan oleh BUMN yang diwujudkan dalam bentuk program PKBL maupun program sosial lain yang disebut dengan istilah BUMN peduli, harus dimaknai sebagai salah satu sarana untuk mencapai tujuan pembangunan nasional yaitu untuk mewujudkan kemakmuran bagi seluruh rakyat Indonesia.

\section{SIMPULAN DAN SARAN}

\section{Simpulan}

Tanggung jawab sosial dan lingkungan pada BUMN adalah amanah undang-undang yang sifatnya wajib sebagai wujud implementasi dari fungsi sosial atau kemanfaatan umum yang diemban oleh BUMN. Agar kemandirian masyarakat dapat terwujud, maka tanggung jawab sosial BUMN harus dilaksanakan secara berkelanjutan, dalam arti bukan hanya rutin setiap tahun, akan tetapi jenis kegiatannya juga harus berkelanjutan mulai dari pemberian pendidikan dan pelatihan, pemberian modal, sampai pada pendampingan usaha. Selain itu Sasaran pelaksanaan program kemitraan BUMN tidak hanya ditujukan pada pengusaha kecil menengah, namun juga harus memberi kesempatan kepada golongan masyarakat yang menganggur atau tidak punya pekerjaan tetap. Mereka dapat dididik dan dilatih terlebih dahulu, kemudian diberikan bantuan modal sehingga mereka dapat berusaha secara mandiri.

\section{Saran}

Program-program sosial yang dijalankan oleh BUMN yaitu program kemitraan dan program bina lingkungan, termasuk kegiatan sosial lain dalam program BUMN peduli hendaknya dapat dilaksanakan secara berkelanjutan. Selain itu 


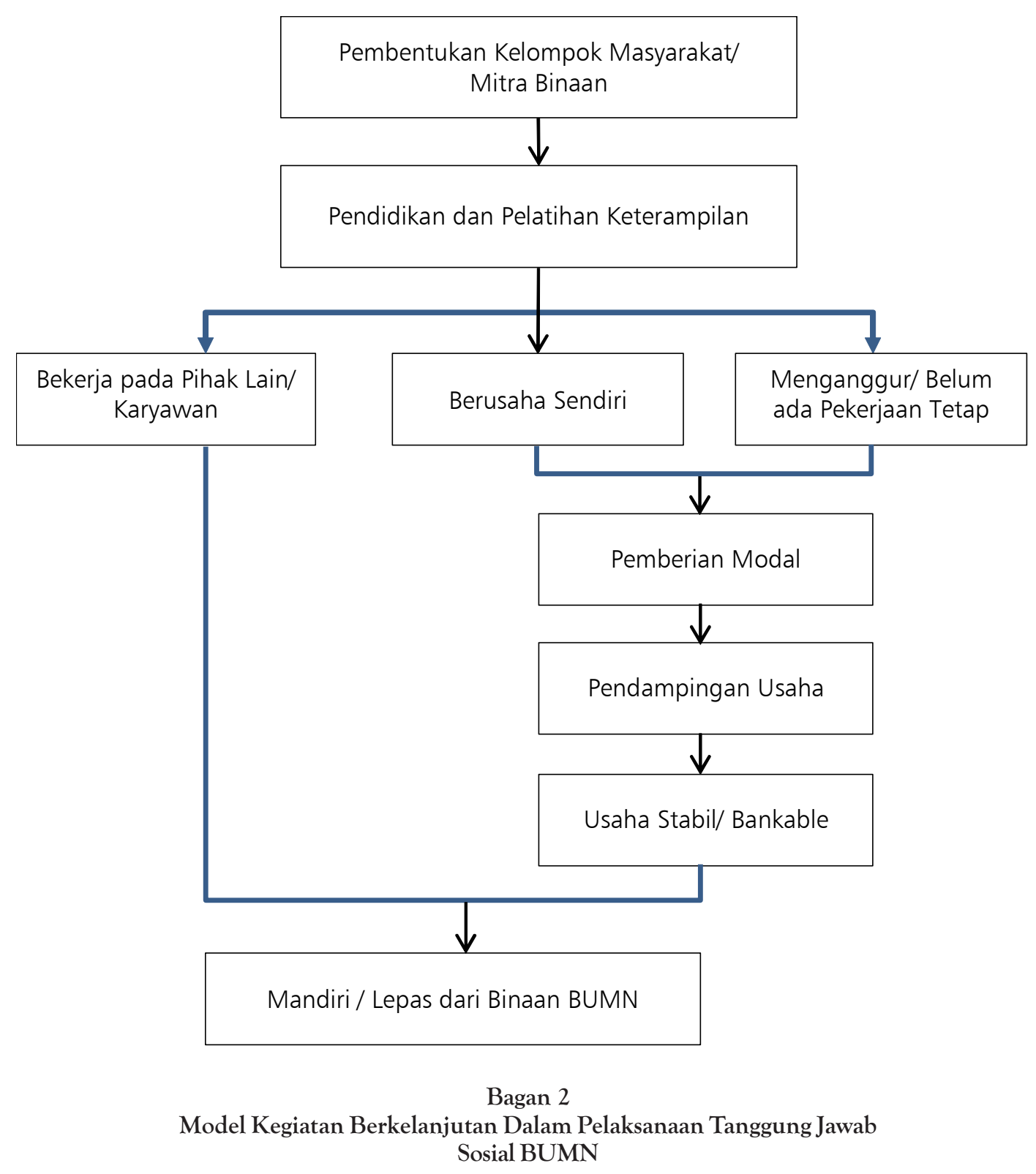

sinkronisasi kegiatan antara program kemitraan dan program bina lingkungan juga perlu dilaksanakan. Hal ini dimaksudkan agar masyarakat yang telah memperoleh bekal keterampilan melalui kegiatan pendidikan dan pelatihan dalam program bina lingkungan, selanjutnya dapat diberi kesempatan untuk mengajukan permohonan bantuan modal usaha melalui program kemitraan.

\section{DAFTAR PUSTAKA}

BPS Sulsel, 2009. Direktori Perusahaan, Katalog 2009.
Makassar.

Fauzan, Uzair dan Heru Prasetyo, 2006, Teori Keadilan, Yogyakarta, Pustaka Pelajar

HR, Ridwan, 2007, Hukum Administrasi Negara, Jakarta, PT. Raja Grafindo Persada

Isnaini Muallidin dan Leli Joko Suryono, Model Kebijakan Pemerintah Daerah dalam Pengelolaan Program Tanggungjawab Sosial Perusahaan Berbasis Regulasi Daerah, Jurnal Media Hukum Volume 22, No.1 Juni 2015

Kartini, Dwi, 2009, Corporate Social Responsibility: 
Transformasi Konsep Sustainability Management dan Implementasi di Indonesia, Bandung, PT. Refika Aditama

Makarim, Edmon, 2010, Tanggung Jawab Hukum Penyelenggara Sistem Elektronik. Jakarta, Rajawali Press

Nursahid, Fajar, 2006. Praktik Kedermawanan Sosial BUMN. Galang, Jurnal Filantropi dan Masyarakat Madani, Vol.1 No.2, January 2006.

Richard A. Posner, 1981, The Economics of Justice, Cambridge, Harvard University Press

Solihin, Ismail, 2008, Corporate Social Responsibility, Jakarta, Salemba Empat

Susiloadi, Priyanto, 2008, Implementasi Corporate Social Responsibility Untuk Mendukung Pembangunan Berkelanjutan. Jurnal Spirit Publik Vol.4 No.2 Oktober 2008

Wibisono, Yusuf, 2007, Membedah Konsep dan Aplikasi CSR, Surabaya, CV.Ashkaf Media Grafika 